\title{
Chemical Constituents of an Iranian Grown Capsicum annuum and their Cytotoxic Activities Evaluation
}

\author{
Masoumeh Foroutan Koudehi ${ }^{1}$, Aria Ashja Ardalan ${ }^{2}$ and Ramin Zibaseresht ${ }^{1,3 *}$ \\ ${ }^{1}$ Biomaterials and Medicinal Chemistry Research Centre, Aja University of Medical Sciences, Iran \\ ${ }^{2}$ Department of Marine Biology, Islamic Azad University- North Tehran Branch, Iran \\ ${ }^{3}$ Department of Chemistry and Physics, Maritime University of Imam Khomeini, Iran
}

Submission: May 27, 2020; Published: June 25, 2020

"Corresponding author: Ramin Zibaseresht, Biomaterials Laboratory, Department of Chemistry and Physics, Faculty of Sciences, Maritime University of Imam Khomeini, Nowshahr, Mazandaran, Iran

\begin{abstract}
A sample of cayenne pepper ,Capsicum annuum -(Family Solanaceae) was collected from a region in Hamadan, west Iran and extracted from EtOH. GC-MS analysis showed at least 8 compounds out of which 7 compounds were isolated and characterized using ${ }^{1} \mathrm{H}$ NMR analysis. Cytotoxic effects of the 7 isolated and characterized compounds along with the extract were evaluated against Caco-2 cell lines using MTT assay. The $\mathrm{IC}_{50}$ values for ethyl palmitate (1), linolelaidic acid ethyl ester (2), ethyl stearate (3), ethyl iso-allocholate (4), 2-(((2-ethylhexyl)oxy)carbonyl) benzoic acid (5), capsaicin (6), dihydrocapsaicin (7) and the extract mixture were determined in $\mu \mathrm{M}(111,112,118,40,130,91,115$, and 110, respectively). The data indicated higher cytotoxic effects of (4) and (6) suggested as potential compounds against Caco-2 cell lines.
\end{abstract}

Keywords: Capsicum annuum; Extraction; GC-MS; NMR; Caco-2; Cytotoxin

\section{Introduction}

Many studies have shown that many species of plants contain a variety of different types of natural products that have different biological activities (1-4). Relatively recently, various studies have shown that natural products extracted from medicinal plants have been considered by the pharmaceutical industry because of their anti-inflammatory, anti-tumor and anti-microbial properties (57). Such biological activities have made them an important source of compounds for the discovery of new drugs. Peppers are among the oldest cultivated plants in the Americas, and archeological remains indicate that Capsicum annuum was used by man even before the advent of agriculture (8). The cayenne pepper ,Capsicum annuum -(Family Solanaceae), is usually a moderately hot chili pepper and is highly flavorful.

Toxicity, carcinogenicity, and anti-tumor activities of Capsicum annuum extracts have been evaluated earlier (9-11). Jang et al. (10) concluded, based on their study, that red chili (Capsicum annuиm) was relatively nontoxic at the doses tested. Other studies revealed that the extracts might have biological activities such as antibacterial (12), antioxidant and anti-inflammatory properties (13). Although in most studies that we explored, mainly either the mixture of extracts or isolated capsaicin, the pungent alkaloid of red pepper (Capsicum annuum ) have been extensively studied for their biological effects $(12,13)$, but less attention has been made towards the cytotoxicity of the extract or the natural products isolated from the extract of Capsicum annuum . Here, we report the extraction, isolation and characterization of some natural products obtained from Capsicum annuum and subsequently the investigation of cytotoxic activities of the extract and isolated natural products against Caco-2 cell line.

\section{Materials and Methods}

\section{General}

Reagent grade commercial solvents were used.

\section{NMR analysis}

The $400 \mathrm{MHz}{ }^{1} \mathrm{H}$ NMR and $100 \mathrm{MHz}{ }^{13} \mathrm{C}$ NMR spectra were acquired on a Bruker-400 spectrometer at Shahid Beheshti University of Medical Sciences. ${ }^{1} \mathrm{H}$ NMR and ${ }^{13} \mathrm{C}$ NMR chemical 
shifts are reported relative to tetramethylsilane. $\mathrm{CDCl}_{3}$ was used as solvent.

\section{GC-MS analysis}

GC-MS analysis of the ethanol extract of Capsicum annuum was performed at Shahid Beheshti University of Medical Sciences using an Agilent 7000-Triple-Quad mass spectrometer coupled with 7890 A gas chromatography. Separation of PAHs was performed using a 5\% phenyl-methyl siloxane (HB-5MS) bondedphase fused-silica capillary column (Hewlett-Packard, $30 \mathrm{~m} \times$ $0.25 \mathrm{~mm}$ i.d., film thickness $0.25 \mu \mathrm{m}$ ). The carrier gas was helium (purity $99.9995 \%$ ) which was further purified by passage through a helium gas purifier Agilent model RMSH-2. The injection port was run in splitless mode and the injection volume was $2 \mu \mathrm{L}$. The oven temperature program was $80^{\circ} \mathrm{C}$ for $1.5 \mathrm{~min}$, raised to $290^{\circ} \mathrm{C}$ at a rate of $50^{\circ} \mathrm{C} / \mathrm{min}$ and maintained at this temperature for $10 \mathrm{~min}$ and the total run time was $15.2 \mathrm{~min}$. The MS transfer line and ion source temperatures were adjusted at $290^{\circ} \mathrm{C}$ and $230^{\circ} \mathrm{C}$, respectively. GC-MS was performed in EI mode. The mass spectra were taken by electronic impact at $70 \mathrm{eV}$; a scan interval of $0.5 \mathrm{~s}$ and fragments from 45 to $450 \mathrm{Da}$. The solvent delay was 0 to $2 \mathrm{~min}$, and the total GC/MS running time was $36 \mathrm{~min}$. The relative percentage amount of each component was calculated by comparing its average peak area to the total areas.

\section{MTT assay}

In vitro cytotoxicity study by MTT assay: Caco-2 cells (human epithelial colorectal carcinoma cells) were cultured in a medium consisting of RPMI-1640, Dulbecco's modified Eagle medium (DMEM), heat-inactivated fetal bovine serum (FBS), and penicillinstreptomycin in a ratio of $50: 34: 15: 1$ at $37^{\circ} \mathrm{C}$ in a humidified incubator with $5 \% \mathrm{CO}_{2}$. Stock solutions of the test compounds were prepared in DMSO solvent and diluted 100 folds with the culture medium. The cells were seeded in 96-well transparent plates at 10,000 cells per well. After 24 hours, the old mediumwas removed and Caco- 2 cells were exposed to the test compounds at concentrations ranging from $0.1-1000 \mu \mathrm{g} / \mathrm{mL}$. After 48 houres incubation, $20 \mu \mathrm{L}$ of MTT solution $(5 \mathrm{mg} / \mathrm{mL})$ was added to each well of the plates and the plates were then maintained in incubator.

After 4 hours, $100 \mu \mathrm{L}$ DMSO solvent was added to each well to dissolve the purple formazan crystals and then the plates were read on a Synergy HT Microplate Reader (Bio-Tek Instruments, Winooski, VT) at $570 \mathrm{~nm}$ with the reference wavelength at $690 \mathrm{~nm}$. The $\mathrm{IC}_{50}$ values were calculated by Sigma Plot 12.0 software. 3-(4,5-dimethylthiaol-2-yl)-2,5-diphenyltetrazolium bromide (MTT) was purchased from Sigma (St Louis, MO, USA). Dulbecco's modified eagle's medium (DMEM), RPMI 1640 medium, and penicillin/streptomycin solution were obtained from Gibco Invitrogen (Carlsbad, CA, USA). Human epithelial colorectal carcinoma (Caco-2) cells were provided by Pasteur Institute, Tehran, Iran.

\section{Results and Discussion}

We have begun a research program aimed at the isolation of natural products from marine or plant sources and investigate their cytotoxic activities for the purpose of anti-tumor properties. In the line of these researches, we have chosen a cayenne pepper (Capsicum annuum- Solanaceae). Although many studies have been undertaken by researchers on this species for their biological activities (5-7,9-13), but as far as our knowledge is concerned, little attention has been made on the investigation of anti-tumor activities of the extracts from this plant. Thus, given the studies on Capsicum annuum extracts, we decided to study the cytotoxicity of Capsicum annuum, and its isolated natural products. For this purpose, we used a cayenne pepper fruit which is grown in Hamadan, west Iran (Figure 1).

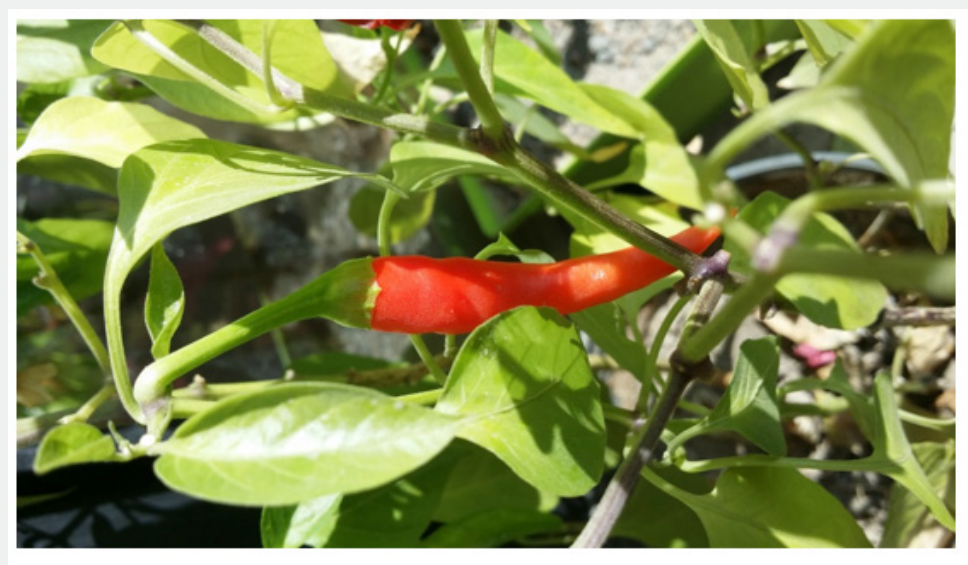

Figure 1: The cayenne pepper (C. annuum - Solanaceae). 


\section{Sample preparation}

The plants were randomly collected from a home garden belonged to Haji-Morad Bashiri cultivated with the assistance of Jeiran Bashiri and Homa Khodabandelou in Hamadan, Iran. The red mature plant fruits were collected, washed with distilled water and air dried under shade and then pulverized into fine particles. The materials $(100 \mathrm{~g})$ were macerated using ethanol for $48 \mathrm{~h}$. The extracts were filtered, and solvent was evaporated in vacuum using a rotary evaporator and stored in refrigerator at $4{ }^{\circ} \mathrm{C}$ until needed for analysis. TLC analysis on silica on plastic (eluting with dichloromethane/ $\mathrm{MeOH}, 10: 1$ ) showed 8 well separated spots suggesting, preliminarily, at least 8 compounds in the extract mixture. The sample of extract was further subjected to column chromatography (silica gel, eluting with dichloromethane/ $\mathrm{MeOH}$, 10:1). The mixture of extract along with the eluents which were collected, were further submitted for GC-MS analysis.

\section{Structural analysis}

As it is shown in Figure 2, GC-MS revealed the presence of 8 compounds with retention time ranging from 20.897 to 25.873 . The maximum peak was shown by capsaicin (81.55\%) followed by ethyl palmitate (6.52\%), 2-(((2-ethylhexyl)oxy)carbonyl)benzoic acid (3.7\%) and (2-methoxy-4-((8-methylnonanoylamino) methyl)phenyl) acetate (3.29\%). On comparison of the mass spectra of the constituents with the NIST library, 8 peaks were recognized out of which 7 phytoconstituents were identified (Table 1). The retention time (RT) is in minutes. Further identification of isolated compounds was conducted using ${ }^{1} \mathrm{H}$ NMR method. In all compounds, the spectra were consistent with the literature (1421).

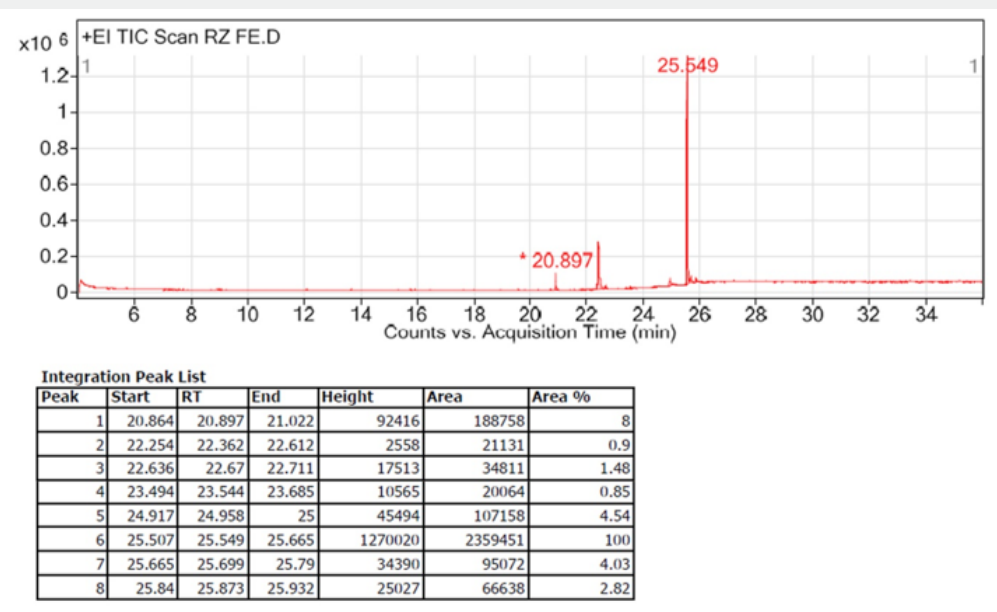

Figure 2: GC-MS spectrum of the extract in $\mathrm{EtOH}$.

With regard to constituent 2, GC-MS analysis suggested that the compound linolelaidic acid ethyl ester, trans-trans isomer, was present in the extract mixture. Although the presence of other stereoisomers such as ethyl $(Z, Z)$-9,12-octadecadienoate was also possible, but the NMR spectra associated with the isolated constituent using column chromatography suggested the presence of trans-trans stereoisomer , i.e. linolelaidic acid ethyl ester, as the only compound as the second constituent of the extract. In order to prove the structure of this compound, the ${ }^{1} \mathrm{H}$ NMR spectrum which was obtained was compared with that of reported for ethyl $(Z, Z)-9,12$-octadecadienoate isomer by Sigmaaldrich database (15) (Figure 3). The differences between the spectra associated with the isomers indicated that, based on the GC-MS spectrum, the compound 2 structure be linolelaidic acid ethyl ester as it is shown in Table 1.

Table 1: The compounds corresponding to 8 peaks which were recognized using NIST library.

\begin{tabular}{|c|c|c|c|}
\hline Peak & $\begin{array}{c}\text { Area } \\
\%\end{array}$ & Chemical Name & $\begin{array}{c}\text { Chemical For- } \\
\text { mula }\end{array}$ \\
\hline 1 & 6.52 & $\begin{array}{c}\text { Hexadecanoic acid, ethyl ester or } \\
\text { Ethyl palmitate }\end{array}$ & $\begin{array}{c}\mathrm{C}_{18} \mathrm{H}_{36} \mathrm{O}_{2} \mathrm{MW}: \\
284.48\end{array}$ \\
\hline 2 & 0.73 & $\begin{array}{c}9,12 \text {-Octadecadienoic acid, ethyl } \\
\text { ester or Linolelaidic acid ethyl ester }\end{array}$ & $\begin{array}{c}\mathrm{C}_{20} \mathrm{H}_{36} \mathrm{O}_{2} \mathrm{MW}: \\
308.50\end{array}$ \\
\hline 3 & 1.21 & $\begin{array}{c}\text { Octadecanoic acid, ethyl ester or } \\
\text { Ethyl stearate }\end{array}$ & $\begin{array}{c}\mathrm{C}_{20} \mathrm{H}_{40} \mathrm{O}_{2} \mathrm{MW} \\
312.53\end{array}$ \\
\hline
\end{tabular}




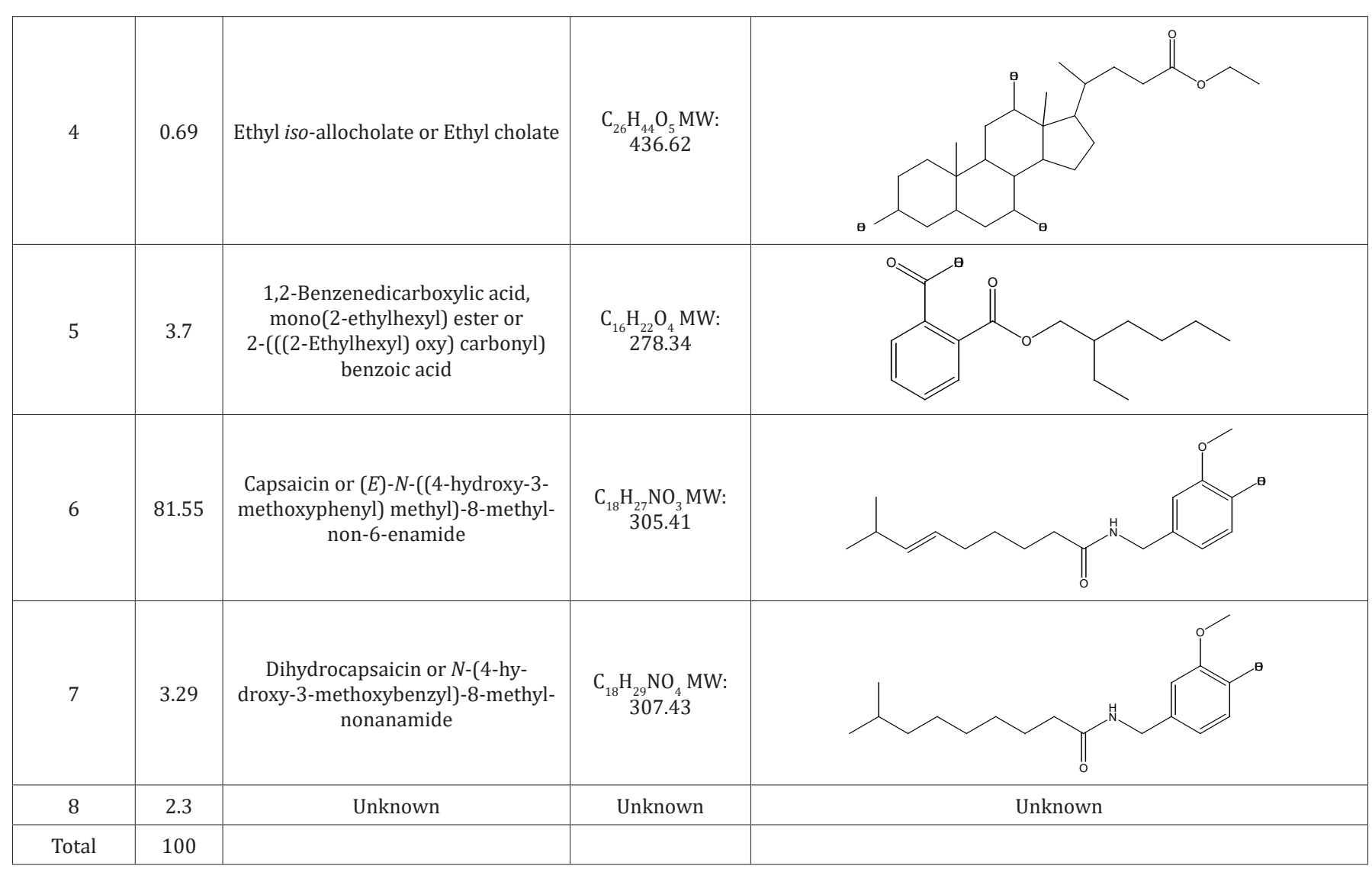

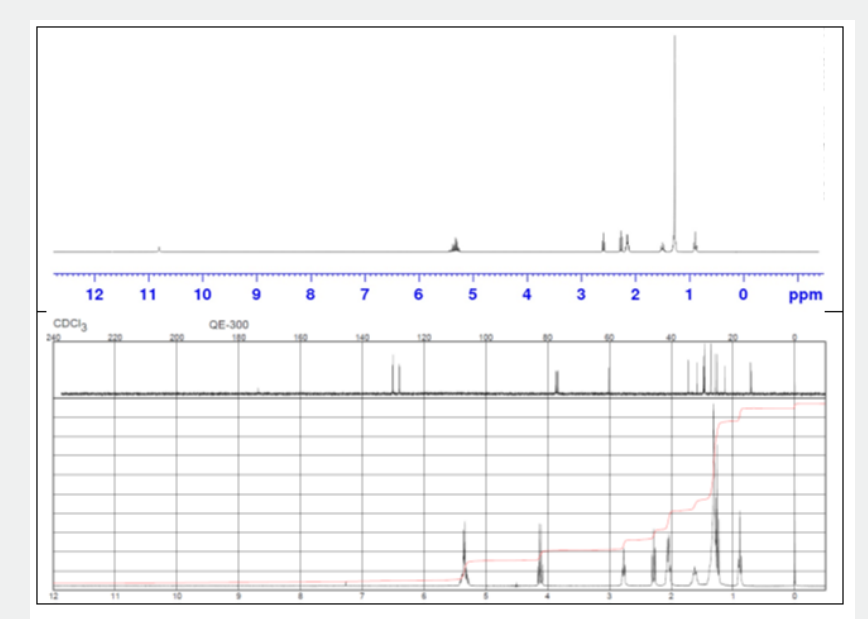

Figure 3: Above: the ${ }^{1} \mathrm{H}$ NMR spectrum corresponding to fraction 2 in $\mathrm{CDCl}_{3}$ solvent, obtained in this study proved the structure of linolelaidic acid ethyl ester, trans-trans isomer; Below: the ${ }^{1} \mathrm{H}$ NMR spectrum corresponding to ethyl $(Z, Z)-9,12$-octadecadienoate isomer from Sigmaaldrich database.

Surprisingly, GC-MS analysis showed the presence of 1,2-benzenedicarboxylic acid, mono(2-ethylhexyl) ester as the fifth fraction of the constituents of the extract mixture. Given in many phytochemical studies, compound 1,2-benzenedicarboxylic acid, bis(2-ethylhexyl) ester were reported as one of the extract constituents, as far as our knowledge is concerned, there is less reports available suggesting compound 1,2-benzenedicarboxylic acid, mono(2-ethylhexyl) ester in their studies (21); therefore, we infer that compound 1,2-benzenedicarboxylic acid, mono(2ethylhexyl) ester, fraction 5, might be of a result of hydrolysis product of 1,2-benzenedicarboxylic acid, bis(2-ethylhexyl) ester.

This kind of decomposition is plausible for a variety of reasons such as contamination during the process of collecting the samples; however, less concentration of this fraction $(3.7 \%)$ along with no evidence of the existence of bis- derivative might 
convince us that such phenomena had not occurred in our study. Therefore, we concluded that the mono-derivative might have been an original compound in the extracts. Although the ${ }^{1} \mathrm{H}$ NMR associated with the isolated fraction 5 was not assigned because of the impurities in the sample, the origin of the fraction 5 remains as an ambiguity in our study. The major constituent in our analysis found to be capsaicin, fraction 6 . The ${ }^{1} \mathrm{H}$ NMR spectrum obtained for this fraction was consistent with the literature (18-20) which in addition to GC-MS analysis supported the structure. The ${ }^{1} \mathrm{H}$ NMR spectrum also indicated that the trans-capsaicin was the isolated isomer (19).

Table 2: Biological activities of the compounds reported in the literature.

\section{Biological activities}

Biological activities of the isolated compounds in this study individually have been studied previously. The sample compounds in other studies, in some cases, have been extracted from other plants sources (Table 2). As the main aim of this research was to investigate the cytotoxicity effect of some isolated compounds from the extract of a sample of cayenne pepper against cancer cell line, we investigated the in vitro effect of the seven isolated and characterized materials along with the mother extract on Caco2 cells (human epithelial colorectal carcinoma cells) using MTT assay.

\begin{tabular}{|c|c|c|c|}
\hline Fraction & Compound & Biological Effects & References \\
\hline 1 & $\begin{array}{l}\text { Hexadecanoic acid, ethyl ester or Ethyl pal- } \\
\text { mitate }\end{array}$ & $\begin{array}{c}\text { Antioxidant, hypocholesterolemic nematicide, pesticide, } \\
\text { flavor, lubricant, anti-androgenic, hemolytic 5-Alpha } \\
\text { reductase inhibitor, } \\
\text { anti-inflammatory potent, } \\
\text { mosquito larvicide. }\end{array}$ & $(22,23)$ \\
\hline 2 & $\begin{array}{l}\text { 9,12-Octadecadienoic acid, ethyl ester or } \\
\text { Linolelaidic acid ethyl ester }\end{array}$ & $\begin{array}{l}\text { Anti-microbial activity, hypocholesterolemic, nematicide } \\
\text { antiarthritic, hepatoprotective anti-androgenic, hypo- } \\
\text { cholesterolemic nematicide, 5-alpha reductase inhibitor, } \\
\text { antihistaminic, } \\
\text { anti-coronary insectifuge, anti-eczemic, ant-iacner }\end{array}$ & $(23,24)$ \\
\hline 3 & Octadecanoic acid, ethyl ester or Ethyl stearate & Anti-microbial & (23) \\
\hline 4 & Ethyl iso-allocholate or Ethyl cholate & $\begin{array}{l}\text { Anti-microbial, anti-cancer, anti-arthritic, anti-asthma, } \\
\text { diuretic, anti-inflammatory }\end{array}$ & $(22,25,26)$ \\
\hline 5 & $\begin{array}{c}\text { 1,2-Benzenedicarboxylic acid, mono(2-ethyl- } \\
\text { hexyl) ester or 2-(((2-Ethylhexyl)oxy)carbon- } \\
\text { yl)benzoic acid }\end{array}$ & Anti-microbial & (27) \\
\hline 6 & $\begin{array}{l}\text { Capsaicin or }(E)-N \text {-((4-hydroxy-3-methoxy- } \\
\text { phenyl) methyl)-8-methylnon-6-enamide }\end{array}$ & $\begin{array}{l}\text { Anti-microbial, anti-inflammatory, antioxidant, to treat } \\
\text { chronic pain syndromes such as post-herpeticneuralgia, } \\
\text { musculoskeletal pain, diabetic neuropathy, osteoarthri- } \\
\text { tis and rheumatoid arthritis, to treat pain from rashes, } \\
\text { psoriasis, mastectomy, and bladder disorders, histone } \\
\text { deacetylase inhibitor }\end{array}$ & $(9,28,29)$ \\
\hline 7 & $\begin{array}{c}\text { Dihydrocapsaicin or } \\
N \text {-(4-hydroxy-3-methoxybenzyl)-8-methyl- } \\
\text { nonanamide }\end{array}$ & $\begin{array}{l}\text { Anti-microbial, anti-inflammatory, antioxidant, histone } \\
\text { deacetylase inhibitor }\end{array}$ & $(9,28,29)$ \\
\hline
\end{tabular}

Table 3 shows the cytotoxic activities of the isolated compounds 1-7 and the extract mixture derivatives against Caco-2 cell lines. The $\mathrm{IC}_{50}$ values in $\mu \mathrm{M}$ were calculated and were compared with the values obtained for some available drugs, Fucoxanthin and Fucoxanthinol (30) (Table 4), and Emodin (31) and Cinnamtannin B-1 (CTB-1) (32) (Table 5) against Caco-2 cell lines. 
Table 3: Cytotoxicity effect of isolated and characterized materials and the mother extract against Caco-2 cells.

\begin{tabular}{|c|c|c|}
\hline Fraction & Compound & IC $_{50}$ values in $\boldsymbol{\mu M}$ \\
\hline Extract mixture & Mixture of at least 8 compounds based on GC-MS analysis & 110 \\
\hline 1 & Hexadecanoic acid, ethyl ester or Ethyl palmitate & 111 \\
\hline 2 & 9,12 -Octadecadienoic acid, ethyl ester oor Linolelaidic acid ethyl ester & 112 \\
\hline 3 & Octadecanoic acid, ethyl ester or Ethyl stearate & 40 \\
\hline 4 & Ethyl iso-allocholate or Ethyl cholate & 130 \\
\hline 5 & $\begin{array}{c}\text { 1,2-Benzenedicarboxylic acid, mono(2-ethylhexyl) ester or 2-(((2-Ethylhexyl) oxy) car- } \\
\text { bonyl) benzoic acid }\end{array}$ & 91 \\
\hline 7 & Dihydrocapsaicin or $N$-(4-hydroxy-3-methoxybenzyl)-8-methylnonanamide & 115 \\
\hline
\end{tabular}

Table 4: Cytotoxicity effect of Fucoxanthin and Fucoxanthinol against Caco-2 cell lines (30).

\begin{tabular}{|c|c|c|c|c|c|c|}
\hline Drug & \multicolumn{3}{|c|}{ Fucoxanthin } & \multicolumn{3}{c|}{ Fucoxanthinol } \\
\hline Concentration & $5 \mu \mathrm{M}$ & $10 \mu \mathrm{M}$ & $20 \mu \mathrm{M}$ & $5 \mu \mathrm{M}$ & $10 \mu \mathrm{M}$ & $20 \mu \mathrm{M}$ \\
\hline $\mathrm{T} / \mathrm{C}(\%)^{*}$ & $91.1 \pm 1.8$ & $96.0 \pm 3.8$ & $73.9 \pm 4.0$ & $79.3 \pm 0.9$ & $55.2 \pm 3.0$ & $1.4 \pm 0.2$ \\
\hline
\end{tabular}

As it was shown in Table 3, ethyl iso-allocholate (fraction 4) followed by capsaicin (fraction 6) showed the highest cytotoxicity against the cultured cells compared to the other compounds we studied and compare with the drugs shown in Tables 4 \& 5, we concluded that, ethyl iso-allocholate (fraction 4) and capsaicin (fraction 6) in the extract can be considered as potential cytotoxic compounds against Caco-2 cell lines. Therefore, we recommend this plant as a plant of phytopharmaceutical importance which might provide ways for the development of several cancer treatments. In addition, based on cytotoxicity of some fractions obtained, it might also be interesting to investigate the effects of the extracts on some viruses including the new SARS-COV-2 virus in the future.

Table 5: Cytotoxicity effect of Emodin (31) and Cinnamtannin B-1 (CTB1) (32) against Caco-2 cell lines.

\begin{tabular}{|c|c|c|}
\hline No & Drug & IC $_{50}$ values in $\boldsymbol{\mu M}$ \\
\hline 1 & Emodin & 30 \\
\hline 2 & Cinnamtannin B-1 (CTB-1) & $32.4 \pm 3.3$ \\
\hline
\end{tabular}

\section{Conclusion}

A number of 7 compounds were isolated and characterized form a sample extract of cayenne pepper. Cytotoxic effects of the compounds and the extract were determined against Caco- 2 cell lines using MTT assay. The $\mathrm{IC}_{50}$ values indicated cytotoxic effects of compounds including (4) and (6) against Caco-2 cell lines.

\section{References}

1. A Thawabteh, S Juma, M Bader, D Karaman, L Scrano, et al. (2019) The Biological Activity of Natural Alkaloids against Herbivores, Cancerous Cells and Pathogens. Toxins 11(11).

2. C Ekeke, TT Manga, SI Mensah (2019) Comparative Phytochemical,
Morphological and Anatomical Studies of Amaranthus hybridus L. and Amaranthus spinosus L. (Amaranthaceae). Res J Med Plants 13(2): 5363.

3. M S Al Aboody, Suresh Mickymaray (2020) Anti-Fungal Efficacy and Mechanisms of Flavonoids. Antibiotics 9(2).

4. Z Adamski, LL Blythe, L Milella, SA Bufo (2020) Biological Activities of Alkaloids: From Toxicology to Pharmacology. Toxins 12(4).

5. OO Oguntibeju (2018) Medicinal plants with anti-inflammatory activities from selected countries and regions of Africa. J Inflamm Res 11: 307-317.

6. FAS Alasmarya, AS Awaad, M Kamal, SI Alqasoumid, ME Zain (2018) Antitumor activity of extract and isolated compounds from Drechslera rostrata and Eurotium tonophilum. Saudi Pharm J 26(2): 279-285.

7. AA Mostafa, AA Al Askar, KS Almaary, TM Dawoud, EN Sholkamy, et al. (2018) Antimicrobial activity of some plant extracts against bacterial strains causing food poisoning diseases. Saudi J Biol Sci 25(2): 361366.

8. B Pickersgill (1969) The domestication of chili peppers. In: PJ Ucko, GW Dimbleby (Eds.), The Domestication and Exploitation of Plants and Animals. Duckworth, London, UK, pp. 443-450.

9. W Johnson (2007) Final Report on the Safety Assessment of Capsicum Annuum Extract, Capsicum Annuum Fruit Extract, Capsicum Annuum Resin, Capsicum Annuum Fruit Powder, Capsicum Frutescens Fruit, Capsicum Frutescens Fruit Extract, Capsicum Frutescens Resin, and Capsaicin. Int J Toxicol 26(1): 3-106.

10. JJ Jang, DE Devor, DL Logsdon, JM Ward (1992) A 4-week feeding study of ground red chili (Capsicum annuum) in male B6C3F1 mice. Food Chem Toxicol 30: 783-787.

11. JP Kim, JG Park, MD Lee, MD Han, ST Park, et al. (1985) Co-carcinogenic effects of several Korean foods on gastric cancer induced by N-methyl$\mathrm{N}$-nitro-N-nitrosoguanidine in rats. Jpn J Surg 15: 427-437.

12. MMP Santos, O Vieira da Motta, IJC Vieira, R Braz Filho, PS Gonçalves, et al. (2012) Antibacterial activity of Capsicum annuum extract and synthetic capsaicinoid derivatives against Streptococcus mutans. J Nat Med 66: 354-356. 
13. K Srinivasan (2016) Biological Activities of Red Pepper (Capsicum annuum) and Its Pungent Principle Capsaicin: A Review. Critical Reviews in Food Science and Nutrition 56(9): 1488-1500.

\section{1H NMR Spectrum (YMDB01349).}

15. https://www.sigmaaldrich.com/spectra/fnmr/FNMR004917.PDF

16. Gerhard Knothe, Alkyl Esters Other than Methyl AOCS Lipid Library.

17. https://shodhganga.inflibnet.ac.in/bitstream/10603/286982/12/12_ chapter\%205.pdf

18. CE Wagner, TM Cahill, PA Marshall (2011) Extraction, Purification, and Spectroscopic Characterization of a Mixture of Capsaicinoids. J Chem Educ 88(11): 1574-1579.

19. LZ Lin, DP West, GA Cordell (1993) NMR Assignments of Cis- and Trans-Capsaicin. Natural Product Letters 3(1): 5-8.

20. TC Valima, DA da Cunhaa, CS Franciscoa, W Romãob, PR Filgueirasa, et al. (2019) Quantification of Capsaicinoids from Chili Peppers using $1 \mathrm{H}$ NMR without Deuterated Solvent. Anal Methods 11(14): 1939-1950.

21. S Manikandaselvi, P Brindha (2014) Chemical Standardization Studies on Capparis Spinosa L. Int J Pharm Pharm Sci 6 (1): 47-54.

22. G Vijayabaskar, V Elango (2018) Determination of Phytocompounds in Withania somnifera and Smilax china Using GC-MS Technique. Journal of Pharmacognosy and Phytochemistry 7(6): 554-557.

23. MN Abubakar, RRT Majinda (2016) GC-MS Analysis and Preliminary Antimicrobial Activity of Albizia adianthifolia (Schumach) and Pterocarpus angolensis (DC). Medicines 3(1): 3.

24. RK Jananie, V Prya, K Vijayalakshmi (2011) Determination of Bioactive Components of Cynodon Dactylon by GC-MS Analysis. New York Sci J 4: 16-20.
25. Aruna L Hugar, Ramesh L Londonkar (2017) GC-MS Profiling of Bioactive Components from Aqueous Extract of Pterocarpus Marsupium. International J ChemTech Res 10(9): 557-564.

26. IH Hameed, HJ Hussein, MA Kareem, NS Hamad (2015) Identification of Five Newly Described Bioactive Chemical Compounds in Methanolic Extract of Mentha viridis by Using Gas Chromatography- Mass spectrometry (GC-MS). J Pharmacognosy Phytother 7(7): 107-125.

27. BP Ezhilan, R Neelamegam (2011) GC-MS Analysis of Phytocomponents in the Ethanol Extract of Polygonum chinense L. Phcog Res 4(1): 11-14.

28. M de Lourdes Reyes Escogido, EG Gonzalez Mondragon, E Vazquez Tzompantzi (2011) Chemical and Pharmacological Aspects of Capsaicin. Molecules 16: 1253-1270.

29. P Kumboonma, T Senawong, K Siriwong, C Yenjai, C Phaosiri (2016) Inhibition of Capsaicin and Dihydrocapsaicin Derivatives Towards Histone Deacetylase and Molecular Docking Studies. Songklanakarin J Sci Technol 38 (4): 399-406.

30. K Takahashi, M Hosokawa, H Kasajima, K Hatanaka, K Kudo, et al. (2015) Anticancer effects of fucoxanthin and fucoxanthinol on colorectal cancer cell lines and colorectal cancer tissues. Oncology Lett 10: 1463-1467.

31. Q Ma, Y Ding, Z Wu, Y Li (2018) Antitumor Effects of Emodin in CACO-2 Human Colon Carcinoma Cells Are Mediated via Apoptosis, Cell Cycle Arrest and Downregulation of PI3K/AKT Signalling Pathway. JBUON 23(3): 588

32. PP Carriere, N Kapur, H Mir, A B Ward, S Singh (2018) Cinnamtannin B-1 inhibits cell survival molecules and induces apoptosis in colon cancer. Int J Oncol 53(4): 1442-1454.

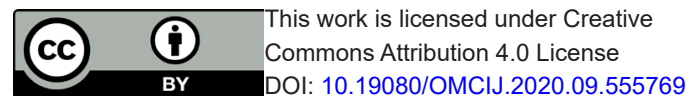

\begin{tabular}{|l|}
\hline \multicolumn{1}{|c|}{ Your next submission with Juniper Publishers } \\
will reach you the below assets \\
- Quality Editorial service \\
- Swift Peer Review \\
- Reprints availability \\
- E-prints Service \\
- Manuscript Podcast for convenient understanding \\
- Global attai nment for your research \\
- Manuscript accessibility in different formats \\
( Pdf, E-pub, Full Text, Audio) \\
- Unceasing customer service \\
Track the below URL for one-step submission \\
https://juniperpublishers.com/online-submission.php \\
\hline
\end{tabular}

